\title{
Efficiency of Using the Reasil Humic Vet Feed Additive in Broiler Chicken Farming
}

\author{
Konstantin Vyacheslavovich Korsakov ${ }^{1 *}$, Alexey Alekseevich Vasiliev ${ }^{1}$, Sergey Pavlovich Moskalenko ${ }^{1}$, Lyubov \\ Alexandrovna Sivokhina ${ }^{1}$, Maxim Yuryevich Kuznetsov ${ }^{1}$ \\ ${ }^{1}$ Saratov State Agrarian University n.a. N. I. Vavilov, 335 Sokolov Str., Saratov, 410005, Russia \\ *Corresponding author E-mail: korsakov.k.v@mail.ru
}

\begin{abstract}
The research has shown the positive influence of the liquid water-soluble combined-effect feed additive Reasil Humic Vet, which consists of a concentrated solution of high-molecular sodium salts of humic acids extracted from leonardite, on the growth vigor, preservation rate and the quality of carcasses of broilers, and confirmed the appropriateness of its use in broiler poultry farming.
\end{abstract}

Keywords: Average daily gain; Broiler chickens; Feed costs; Humic acid; Slaughter yield.

\section{Introduction}

Since long ago, the mankind has been facing the problem of providing necessary food products to the population. The constant growth of the world's population inevitably results in the introduction of innovations in the agriculture. Intensification of agriculture requires that the modern agrarian introduces and masters new technologies, with the main objective of increasing the production volumes, improving the quality, and lowering the costs per unit of yield.

One of the main principles in the agriculture worldwide, including poultry farming, is the principle of environmental safety, and the main expense item in livestock breeding is the cost of the feed. Its quality and diet balance determine all main quality characteristics of the ready product, and its cost $[4,5,6]$. Feed quality and poultry resistance may be improved by introducing humic acids and their derivatives into the diet $[1,2,3,7,8]$.

The Reasil biologically active feed additive made by LLC Life Force from humic acids based on leonardite combines the properties of an intestinal sorbent for mycotoxins and pesticide residues, an immune stimulator and antagonist of pathogenic flora, and a stimulator of protein synthesis and muscle growth.

\section{Methods}

Efficiency of using the liquid water-soluble combined effect feed additive Reasil Humic Vet based on the concentrated solution of high-molecular sodium salts of humic acids extracted from leonardite was studied at the Department of Veterinary Medicine and Biotechnology of the FSBEI of Higher Education Saratov State Agricultural University.

The research was aimed at studying the effect of the Reasil Humic Vet feed additive in the amount of $0.5 \mathrm{ml} /$ liter of water on the productivity of broiler chickens and on the quality of meat products. The studied preparation was introduced into the diet of broiler chickens with drinking water. The experiment was performed in the 2 experimental groups of chickens as shown in Table 1.
Table 1: Experiment layout

\begin{tabular}{|c|c|c|c|}
\hline Group & Population & $\begin{array}{c}\text { Duration of the } \\
\text { experiment, days }\end{array}$ & Feeding conditions \\
\hline 1 - reference & 100 & 42 & MD (main diet) \\
\hline $\begin{array}{c}2 \text { - experi- } \\
\text { mental }\end{array}$ & 100 & 42 & $\begin{array}{c}\text { MD }+0.5 \text { ml of Reasil } \\
\text { Humic Vet per liter of } \\
\text { water }\end{array}$ \\
\hline
\end{tabular}

All experimental groups of chickens received the combined feed prepared at the feed mill of IE A. Korostin in the Marksovsky district of the Saratov region. Composition and nutritional value of the combined feeds are shown in Table 2. The chickens were weighed on a weekly basis.

Table 2: Feed composition and nutritional value

\begin{tabular}{|c|c|}
\hline Composition & Amount, \% \\
\hline Wheat & 40.61 \\
\hline Maize & 15.00 \\
\hline Full-fat soya beans (crude fat $31.5 \%$, crude protein $17 \%$ ) & 24.62 \\
\hline Soybean cake (crude protein $45 \%$ ) & 12.00 \\
\hline Sunflower cake (crude protein $34 \%$, crude fiber $18 \%$ ) & 3.00 \\
\hline Fish flour (crude protein $64 \%$ ) & 1.49 \\
\hline Monocalcium phosphate & 0.53 \\
\hline Lime dust & 0.75 \\
\hline Premix 2\% PK5 agrostimul & 2.00 \\
\hline \multicolumn{2}{|l|}{ Nutritional value } \\
\hline Exchange energy+phytase, Kcal/100 & 311.00 \\
\hline Exchange energy of poultry, Kcal/100 & 301.00 \\
\hline Crude protein & 22.00 \\
\hline Crude fat & 6.14 \\
\hline Linoleic acid & 3.10 \\
\hline Crude fiber & 4.5 \\
\hline Lysine & 1.43 \\
\hline Methionine & 0.62 \\
\hline Methionine + cystine & 0.92 \\
\hline Threonine & 0.87 \\
\hline Tryptophan & 0.25 \\
\hline $\mathrm{Ca}$ & 1.00 \\
\hline $\mathrm{P}$ & 0.84 \\
\hline
\end{tabular}




\begin{tabular}{|c|c|}
\hline P digestible & 0.50 \\
\hline $\mathrm{Na}$ & 0.20 \\
\hline $\mathrm{Cl}$ & 0.17 \\
\hline $\mathrm{NaCl}$ & 0.10 \\
\hline
\end{tabular}

The combined feed included feeds that satisfied the need of broiler chickens in exchange energy, minerals, nutrients, essential amino acids, and vitamins.

\section{Results}

Chickens were weighed weekly from the 7-th day of life. The first weighing at the beginning of the experiment showed that chickens in both groups had almost the same live weight. Deviation in groups from the reference was $1.8 \%$ (Table 3 ).

As soon as within the first week of receiving the feed additive, the chickens in the second group had shown higher growth rate - by $1.73 \mathrm{~g}$, which ensured achieving the average live weight higher by $15.56 \mathrm{~g}$, compared to the peers in the reference group.

The results of weight check at the age of 21 days showed that the chickens in the experimental group continued gaining superiority in both live weight and the average daily weight gain by 14 and $24.5 \%$.

The results of the 4th weight check indicated a significant increase in the average daily weight gains in both groups. However, the difference in the average live weight between groups 1 and 2 was more significant, and amounted to $99.0 \mathrm{~g}$.

The next time the weight was checked at the age of 35 days. The results showed a steady increase in the live weight of young poultry in group 2 who received $0.5 \mathrm{ml}$ of the feed additive per 11 of drinking water. The average daily gains of chickens exceeded those in the reference group by $8.3 \%$. The final weight check was performed at the age of 42 days.

In the last week of growing, a steady increase in the productivity of the chickens in group 2 was noted. According to the results of weight check, their live weight and the average daily gain exceeded those in the reference group by $20.1 \%$. The results of growing showed that the chickens in group 2 exceeded their peers from the reference group in terms of the average daily gain by $11.8 \%$. This difference ensured higher gross increment, and, consequently, growing chickens with noticeably higher live weight.

Table 3: Dynamics of broiler chickens' live weight and feed costs

\begin{tabular}{|c|c|c|}
\hline Indicator & \multicolumn{2}{|c|}{ Group } \\
\cline { 2 - 3 } & 1 & 2 \\
\hline $\begin{array}{c}\text { Live weight at the beginning of } \\
\text { the experiment, } \mathrm{g}\end{array}$ & $93.33 \pm 2.45$ & $91.67 \pm 1.56$ \\
\hline $\begin{array}{c}\text { Live weight at the end of } \\
\text { the experiment, } \mathrm{g}\end{array}$ & $2,538 \pm 19.8$ & $2,826 \pm 21.4^{* * *}$ \\
\hline Gross gain per 1 bion., $\mathrm{g}$ & $2,444.67 \pm 17.2$ & $2,734.33 \pm 15.8^{* *}$ \\
\hline Average daily gain, $\mathrm{g}$ & $64.33 \pm 1.4$ & $71.95 \pm 2.1^{* *}$ \\
\hline \% to the reference & 100.00 & 111.85 \\
\hline Feed cost per 1 kg of gain, $\mathrm{kg}$ & 2.23 & 1.93 \\
\hline Preservation rate, $\%$ & 95.1 & 96.8 \\
\hline
\end{tabular}

**- $\mathrm{P}<0.01 ; * * * \mathrm{P}<0.001$

The best results of using nutrients and energy were reached in this group. For reaching $1 \mathrm{~kg}$ of growth gain, the chickens that received the Reasil Humic Vet feed additive needed $0.3 \mathrm{~kg}$, or $13.5 \%$ less feed than those in the reference group.

The overall results for the experiment period confirmed the efficiency of feeding the Reasil Humic Vet feed additive to the chickens at the rate of $0.5 \mathrm{ml}$ per liter of water. This ratio and the method of feeding were the most optimal, as they had supported growth stability virtually throughout the entire experiment.

At the end of the experiment, poultry check-out slaughter was performed, the results of which are shown in Table 4.

Table 4: Results of check-out slaughter $(n=3)$

\begin{tabular}{|c|c|c|}
\hline \multirow{2}{*}{ Indicator } & \multicolumn{2}{|c|}{ Group } \\
\cline { 2 - 3 } & 1 & 2 \\
\hline Weight before slaughter, $\mathrm{g}$ & $2,511.7 \pm 19.2$ & $2,788.4 \pm 20.4 * * *$ \\
\hline Weight of non-eviscerated carcass, $\mathrm{g}$ & $2,308.3 \pm 20.1$ & $2,578.3 \pm 18.7 * * *$ \\
\hline
\end{tabular}

\begin{tabular}{|c|c|c|}
\hline Weight of half-eviscerated carcass, $\mathrm{g}$ & $2,086.6 \pm 19.2$ & $2,385.5 \pm 18.8^{* * *}$ \\
\hline $\begin{array}{c}\text { Weight of eviscerated carcass (fresh } \\
\text { drawn), } \mathrm{g}\end{array}$ & $1,867.2 \pm 17.4$ & $2,088.3 \pm 19.7^{* * *}$ \\
\hline Slaughter yield, \% & $74.34 \pm 0.78$ & $74.89 \pm 0.56$ \\
\hline
\end{tabular}

**- $\mathrm{P}<0.014 ; * * * \mathrm{P}<0.001$

The results of slaughtering showed that feeding the Reasil Humic Vet feed additive with drinking water influenced the slaughter yield. The highest value was observed in the chickens from group $2-74.89 \%$, which was greater than in the chickens from the reference group by $0.55 \%$. Due to higher slaughter weight, the chickens were distinctly superior in terms of other control slaughter values. The results of anatomical evisceration showed that the weight of muscles as percentage to the eviscerated carcass in group 2 was higher than in reference group by $111.3 \mathrm{~g}$ (Table 5)

Table 5: Morphological composition of carcasses and the weight of internal organs of broilers $(n=3)$

\begin{tabular}{|c|c|c|}
\hline \multirow{2}{*}{ Indicator } & \multicolumn{2}{|c|}{ Group } \\
\cline { 2 - 3 } & 1 & 2 \\
\hline Weight of muscles with skin, $\mathrm{g}$ & $1,337 \pm 17.4$ & $1,465 \pm 19.7^{* *}$ \\
\hline Weight of skin with subcutaneous fat, & $197.1 \pm 4.5$ & $213.8 \pm 6.7$ \\
\hline $\mathrm{g}$ & & \\
\hline \%eight of muscles, $\mathrm{g}$ & $1,139.9 \pm 15.1$ & $1,251.2 \pm 18.2^{* *}$ \\
\hline of the weight of eviscerated carcass & $61.0 \pm 1.1$ & $65.2 \pm 0.8^{*}$ \\
\hline Visceral fat, $\mathrm{g}$ & $24.3 \pm 1.0$ & $31.0 \pm 0.9^{* *}$ \\
\hline Edible parts (muscles + skin + fat) & $1,361.3 \pm 19.1$ & $1,496.0 \pm 16.3$ \\
\hline \% to the reference & 100.0 & 109.8 \\
\hline Weight of heart, $\mathrm{g}$ & $13.96 \pm 0.53$ & $16.86 \pm 0.45^{*}$ \\
\hline Liver without bile, $\mathrm{g}$ & $49.90 \pm 1.09$ & $61.20 \pm 1.65^{* *}$ \\
\hline Spleen, $\mathrm{g}$ & $2.23 \pm 0.12$ & $3.03 \pm 0.21^{*}$ \\
\hline Pancreas, $\mathrm{g}$ & $3.96 \pm 0.1$ & $4.50 \pm 0.08^{*}$ \\
\hline Gall bladder, $\mathrm{g}$ & $2.60 \pm 0.1$ & $4.00 \pm 0.18^{* *}$ \\
\hline Gizzard stomach, $\mathrm{g}$ & $27.76 \pm 0.27$ & $29.66 \pm 0.43$ \\
\hline Visceral fat, $\mathrm{g}$ & $24.36 \pm 1.5$ & $39.0 \pm 1.0^{* *}$ \\
\hline
\end{tabular}

$*_{\text {- }} \mathrm{P}<0.1 ; *_{\text {- }} \mathrm{P}<0.01 ; * * * \mathrm{P}<0.001$

By the contents of edible parts, the best were the chickens in the same group with this indicator higher than in the reference group by $9.8 \%$. The content of visceral fat in group 2 exceeded that in the reference group by $6.7 \mathrm{~g}$.

The work of internal organs is of great importance for the growth and development of skeleton, muscles and other tissues of the organism. At the age of 42 days, the maximum weight of the heart was observed in the chickens from group $2(16.86 \mathrm{~g})$, which was more than that in the reference group by $20.7 \%$. The same regularity was observed for the weight of the liver, the spleen, and the gallbladder.

In the chickens from the reference group, the weight of pancreas was lower than that in the experimental chickens from group 2 by $13.6 \%$. The weight of stomach of the chickens in experimental group 2 was higher than in the reference group by $6.8 \%$. The significantly higher live weight of the chickens who received Reasil Humic Vet was the reason of the higher values of all studied indicators of check-out slaughter, carcass morphological composition and the weight of visceral organs of the broilers.

\section{Conclusion}

The introduction of the Reasil Humic Vet feed additive in the amount of $0.5 \mathrm{ml} / 1$ of water contributed to increasing the growth rate of broiler chickens by $7.62 \mathrm{~g}$, or by $11.8 \%$, and to reducing the feed cost per $1 \mathrm{~kg}$ of growth by $0.3 \mathrm{~kg}$ of the combined feed, or by $13.5 \%$, compared to their peers from the reference group.

Feeding the Reasil Humic Vet feed additive with drinking water increased the carcass slaughter yield by $0.55 \%$. The chickens in the 2nd experimental group superseded their peers in the reference group in terms of muscle weight by $111.3 \mathrm{~g}$, or by $4.2 \%$ from the weight of eviscerated carcass, and in terms of the content of edible parts - by $135 \mathrm{~g}$, or by $9.8 \%$. The maximum amount of fat was observed in group $2-31.0 \mathrm{~g}$, which was by $6.7 \mathrm{~g}$, or by $27.5 \%$ more than in the reference group. 
The obtained data allow recommending the liquid water-soluble combined-effect feed additive Reasil Humic Vet, which consists of a concentrated solution of high-molecular sodium salts of humic acids extracted from leonardite, as a feed additive in growing broiler chickens at all types of poultry farms.

\section{References}

[1] Andrianova EN, Egorov IA, Shevlyakov AN, et al. (2017), Helaty na osnove guminovih soedinenii $\mathrm{v}$ kormlenii tsiplyat-broilerov [Chelates based on humic compounds in feeding of broiler chickens]. Poultry Farming 11, 12-16.

[2] Buzlama VS, Dolgopolov VN \& Safonov VN (2006), Mehanizm deistviya preparatov guminovih veschestv [The mechanism of action of humic substances] Proceedings of Conference Results and prospects of using humic substances in productive cattle breeding, horse breeding and poultry farming. Moscow, 24-33.

[3] Vasiliev AA., Korobov AP, Moskalenko SP, Sivokhina LA \& Kuznetsov MY (2018), Znachenie, teoriya i praktika ispol'zovaniya guminovih kislot $\mathrm{v}$ zhivotnovodstve [The importance, the theory and the practice of using humic acids in cattle breeding]. Agrarian Scientific Journal 1, 3-6.

[4] Vasiliev AA, Korobov AP, Moskalenko SP, Sivokhina LA \& Kuznetsov MY (2015), Effektivnost ispolzovaniya gidroponnogo zelenogo korma v ratsionah kur-nesushek [Efficiency of using hydroponic green feed in the diets of laying hens]. Agrarian Scientific Journal 1, 14-17.

[5] Vasiliev AA, Korobov AP, Moskalenko SP, Sivokhina LA \& Kuznetsov MY (2015), Vliyanie gidroponnogo zelenogo korma na perevarimost' pitatel'nih veschestv i obmen azota, kaltsiya i fosfora v organizme kur - nesushek krossa Haiseks korichnevii [The influence of hydroponic green feed on the digestibility of nutrients and the metabolism of nitrogen, calcium and phosphorus in the organism of Hisex brown laying hens]. International Scientific and Practical Conference Modern Methods of Improving Productive Qualities of Cattle, Poultry and Fish in the Light of Import Substitution and Food Security of the Country, 202-207.

[6] Vasiliev AA, Korobov AP, Moskalenko SP, Sivokhina LA \& Kuznetsov MY (2017), Gidroponnii zelenii korm v ratsionah nesushek [Hydroponic green feed in the diets of laying hens]. Animal Breeding in Russia 7, 13-15.

[7] Zhilyakova TP \& Kostecha NI (2006), Primenenie guminovoi kormovoi dobavki gumiton $\mathrm{v}$ ptitsevodstve [Using the Humiton humic feed additive in poultry farming]. Modern problems and achievements of the agricultural science in animal breeding, crop production and economy: Collection. of works of the regional scientific-practical conference.Tomsk, Publishing House UFO Print, 9, 84-87.

[8] Stepchenko LM, Gorina LV \& Kravtsova LV (1991), Vliyanie gumata natriya na obmen veschestv i rezistentnost visokoproduktivnoi ptitsy [The influence of sodium humate on metabolism and resistance of highly productive poultry]. Higher school scientific reports. Biological Sciences 10(334). 